\title{
UPAYA PEMENUHAN HAK PELAYANAN KESEHATAN KEPADA NARAPIDANA DI LEMBAGA PEMASYARAKATAN
}

\section{Faldi Biaggy ${ }^{1}$, Padmono Wibowo ${ }^{2}$}

${ }^{1}$ Manajemen Pemasyarakatan, Politeknik Ilmu Pemasyarakatan, email: biaggyfaldi@gmail.com

\begin{abstract}
ABSTRAK
Penelitian ini bertujuan untuk mengetahui proses pemenuhan hak narapidana dalam mendapatkan pelayanan kesehatan dan makanan yang layak dalam tinjauan undang-undang, maupun kendala yang dihadapi pihak lapas dalam memberikan pelayanan kesehatan dan makanan yang layak di Lembaga Pemasyarakatan. Penelitian ini lebih merupakan penelitian hukum normatif. Penelitian ini lebih berfokus pada data sekunder. Bahan hukum sekunder yang utama adalah dari undang-undang terkait hak kesehatan narapidana. Metode analisa data yang digunakan adalah analisis kualitatif. Berdasarkan dari penelitian yang dilakukan dapat disimpulkan bahwa pemenuhan hak narapidana untuk mendapatkan pelayanan kesehatan dan makanan yang layak dalam tinjauan undang-undang di Lembaga Pemasyarakatan belum berjalan baik karena berbagai macam kendala yang dihadapi pihak Lapas, kendala - kendala tersebut antara lain adalah over capacity yang terjadi di Lapas, masih kurangnya petugas keahlian khusus dibidang kesehatan yang ada di Lapas dan juga pihak Lapas masih terkendala masalah anggaran dana yang terbatas.
\end{abstract}

\section{ARTICLE INFO}

Kata Kunci:

Hak Kesehatan

Narapidana; Lembaga

Pemasyarakatan;

Undang-Undang.

Cite this paper:

Faldi Biaggy, P. W.,

2020. Upaya

Pemenuhan Hak

Pelayanan Kesehatan

Kepada Narapidana Di

Lembaga

Pemasyarakatan. Widya

Yuridika: Jurnal Hukum,

3(2).

\section{PENDAHULUAN}

Negara Indonesia adalah Negara hukum. Hal tersebut dengan tegas dijelaskan dalam Undang-Undang Dasar Negara Republik Indonesia Tahun 1945 (UUD NRI 1945) Pasal 1 ayat (1). Dengan pengertian tersebut, maka Indonesia menjunjung tinggi hukum itu sendiri sebagai acuan nilai bagi masyarakat, termasuk untuk menyelesaikan berbagai permasalahan baik dalam kehidupan bermasyarakat maupun bernegara. Maka dari itu, sudah menjadi tugas dan tanggung jawab bagi seluruh warga negara Indonesia tanpa terkecuali, untuk menjaga serta mengamalkan hukum agar hukum tetap berdiri tegak di Indonesia. Dalam rangka menegakkan Negara hukum di Indonesia sebagaimana yang di cita-citakan, diperlukan usaha agar masyarakat mengenal asal mula hukum yang berlaku. 
Namun, dalam usahanya untuk mencapai hal tersebut, masyarakat sering kali menjumpai berbagai rintangan yang ditimbulkan, antara lain adanya pelanggaran hukum atau pelaku kejahatan.

Pelanggaran hukum atau pelaku kejahatan akan selalu muncul di tengah-tengah masyarakat walaupun cara pencegahannya telah dilaksanakan. Negara juga telah mempunyai suatu lembaga yang di peruntukkan khusus untuk menangani kejahatan tersebut, tetapi kejahatan tetap saja muncul dengan gaya baru dan modusoperasi yang baru, sesuai dengan perkembangan zaman. Setiap pelanggaran hukum, dalam penegakan hukum pidana akan di proses melalui berbagai tahap sesuai dengan sistem peradilan pidana yang ada di Indonesia. Ketika hakim telah memutuskan suatu perkara melanggar hukum, maka selanjutnya yang diberikan kepada pelanggar tersebut adalah pemidanaan. Pemidanaan atau penjatuhan pidana dilakukan terhadap seseorang yang terbukti melakukan tindak pidana.

Pemberian pemidanaan tersebut, bukan hanya semata-mata bertujuan untuk pembalasan terhadap perbuatan yang dilakukannya, namun pidana penjara merupakan salah satu jenis sanksi pidana yang paling sering digunakan dalam menanggulangi masalah kejahatan. Dalam penerapannya, kenyataan empiris di bidang pemidanaan secara umum masih menganut pemahaman bahwa pemidanaan hanya untuk sekedar memperbaiki terpidana di Lembaga Pemasyarakatan, sehingga memberikan gambaran bahwa kejahatan tersebut hanya terhenti sesaat dan akan muncul kembali dalam lingkungan kehidupan social masyarakat. Dibutuhkan suatu sistem agar narapidana menyadari kesalahannya, tidak lagi berkehendak untuk melakukan tindak pidana dan kembali menjadi warga masyarakat yang bertanggung jawab bagi diri, keluarga, dan lingkungannya dan system tersebut merupakan sistem pemasyarakatan.

Dalam Undang-Undang Republik Indonesia Nomor 12 Tahun 1995 Tentang Pemasyarakatan, sistem pemasyarakatan adalah suatu tatanan mengenai arah dan batas serta cara pembinaan Warga Binaan Pemasyarakatan berdasarkan Pancasila yang dilaksanakan secara terpadu antara pembina, yang dibina, dan masyarakat untuk meningkatkan kualitas Warga Binaan Pemasyarakatan agar menyadari kesalahan, memperbaiki diri, dan tidak mengulangi tindak pidana sehingga dapat diterima kembali oleh lingkungan masyarakat, dapat aktif berperan dalam pembangunan, dan dapat hidup secara wajar sebagai warga yang baik dan bertanggung jawab ${ }^{1}$. Sistem Pemasyarakatan disamping bertujuan untuk mengembalikan warga binaan pemasyarakatan sebagai warga yang baik, juga bertujuan untuk melindungi masyarakat terhadap kemungkinan diulanginya tindak pidana oleh warga binaan pemasyarakatan, serta merupakan penerapan dan bagian yang tak terpisahkan dari nilai-nilai yang terkandung dalam Pancasila. Oleh karena itu, dalam sistem pemasyarakatan ini tetap mengutamakan hakhak narapidana sebagai warga Negara Indonesia yang hilang kemerdekannya karena melakukakan hukuman pidana di Lembaga Pemasyarakatan dengan tetap menerapkan hak asasi manusia.

${ }^{1}$ Undang-Undang nomor 12 tahun 1995, tentang Pemasyarakatan Pasal 1 angka 2 
Sering ditemukan dalam Lembaga Pemasyarakatan, bahwa hak-hak narapidana belum diberikan seutuhnya sesuai dengan hak mereka sebagai warga Negara. Hal idi bisa disebabkan dari berbagai hal, seperti kurangnya pemahaman akan hak-hak narapidana yang tercantum dalam Undang-Undang oleh para petugas pemasyarakatan di Lembaga Pemasyarakatan atau bahkan dari narapidana sendiri. Sebagai negara hukum hak-hak narapidana harus dilindungi oleh hukum, selain itu juga narapidana harus diayomi oleh para petugas dari perlakuan tidak adil seperti penyiksaan, tidak mendapatkan fasilitas yang wajar tidak adanya kesempatan untuk mendapatkan remisi serta perbedaan perlakuan dalam haknya untuk mendapatkan hak kesehatan. Dalam Undang-undang Republik Indonesia Nomor 12 Tahun 1995 tentang Permasyarakatan menyebutkan bahwa salah satu hak dari narapidana adalah mendapatkan pelayanan kesehatan dan makanan yang layak. Pemenuhan pelayanan kesehatan ini tidak hanya menyangkut penciptaan lingkungan yang baik, perlakukan yang sama, tapi termasuk pula pembenaan pelayanan kesehatan secara manusiawi yang diarahkan pada tingkatan harkat dan martabat, sehingga diharapkan dapat mengembangkan suatu masyarakat yang berkepribadian, yang saling menghormati yang menjunjung tinggi. Dalam konsepnya bahwa sistem Pemasyarakatan memperlakukan orang lebih manusiawi dari pada sistem kepenjaraan Narapidana dalam melaksanakan program pembinaan harus dalam kondisi sehat.

Dengan sistem yang telah berjalan, seharusnya pemenuhan hak pelayanan kesehatan kepada narapidana harus maksimal dilakukan. Bahwa narapidana berhak untuk tidak diperlakukan sebagai orang sakit yang diasingkan, maka narapidana juga berhak atas pelayanan kesehatan selayaknya masyarakat banyak. Meningkatkan kesehatan dan keselamatan warga binaan pemasyarakatan berarti membuktikan bahwa Lembaga Pemasyarakatan perlu memperhatikan kesehatan narapidana secara menyeluruh, jika tidak maka akan menimbulkan keadaan bahaya bagi petugas dan warga binaan pemasyarakatan karena pelanggaran tersebut akan menimbulkan dampak yang tidak baik. Upaya memenuhi hak-hak narapidana di atas masih banyak yang hanya sebatas pengakuan saja dalam perundang-undangan namun implementasianya masih jauh dari realita. Hal ini karena dalam pelaksanaannya banyak sekali hambatan-hambatan yang muncul, seperti kelayakan lembaga pemasyarakatan di daerah, sarana dan prasarana, kurangnya personil, hingga kendala terkait over kapasitas penghuni lapas. Pemerintah juga memiliki peran yang sangat penting didalam melakukan pemenuhan pelayanan kesehatan bagi narapidana, hal ini sangat terkait dengan fungsi pemerintah sebagai alat untuk selalu meningkatkan kesehatan masyarakatnya termasuk narapidana ${ }^{2}$.

Dalam Lembaga Pemasyarakatan tidak semuanya narapidana dalam kondisi sehat, bagi narapidana yang sakit harus mendapatkan pelayanaan kesehatan yang optimal, menurut Undang-Undang No.23 Tahun 1992 Tentang Kesehatan, kesehatan adalah tercapainya kesadaran, kemampuan dan kemauan 5 hidup sehat setiap penduduk agar dapat mewujudkan hidup sehat yang optimal, berarti setiap orang tanpa memandang ras, agama, politik yang dianut, dan ekonomi, diberikan hak pelayanaan kesehatan demikian pula bagi narapidana yang sedang menjalani masa pidananya di Lembaga

2 Jumalia. Pontianak, Peran Pemerintah Dalam Pemenuhan Hak Narapidana Untuk Memperoleh Pelayanan Kesehatan 
Pemasyarakatan. Pelayanan kesehatan yang diberikan di Lembaga Pemasyarakatan merupakan salah satu pemberian Hak Asasi Manusia dari negara kepada warganya.

Pelayanan kesehatan yang baik bagi narapidana tidak terlepas dari tersediannya sarana dan prasarana kesehatan. Sudah seharusnya bahwa pelaksanaan hak pelayanan kesehatan kepada narapidana dilakukan sesuai dengan tinjauan undang-undang. Hal ini dianggap sulit, karena kondisi yang diharapkan dalam undang-undang dirasa sulit untuk dilaksanakan apabila kita melihat kondisi Lapas realitanya. Dalam tinjuan undangundang dirasa bahwa kondisi Lapas sudah memadai, sehingga dapat melaukan peraturan tersebut. Namun yang terjadi sebaliknya, kondisi sarana dan prasarana kesehatan di Lembaga Pemasyarakatan masih bisa dikatakan belum memadai. Kondisi ini tentunya akan mengakibatkan timbulnya masalah-masalah baru di dalam Lembaga Pemasyarakatan. Masalah yang dominan terjadi akibat kondisi yang demikian ini adalah adanya penurunan tingkat kesehatan bagi narapidana.

Oleh karena itulah kiranya perlu dikaji kembali bagaimanakah proses pemenuhan hak-hak Narapidana atas pelayanan kesehatan dalam tinjauan undang-undang, dan apa saja kendala yang dihadapi dalam melaksanakan hak narapidana atas pelayanan kesehatan di Lembaga Pemasyarakatan. Penelitian ini lebih merupakan penelitian hukum normatif. Pendekatan dalam penelitian ini menggunakan pendekatan normative. Penelitian ini lebih berfokus pada data sekunder.

\section{HASIL DAN PEMBAHASAN}

Seluruh manusia terlahir dengan memiliki hak. Manusia memiliki hak bukan karena diberikan kepadanya oleh masyarakat, melainkan semata-mata berdasarkan martabatnya sebagai manusia. Hak asasi manusia adalah hak-hak yang dimiliki manusia semata-mata karena ia manusia. Dalam arti ini, maka meskipun setiap orang terlahir dengan warna kulit, jenis kelamin, bahasa, budaya dan kewarganegaraan yang berbedabeda, ia tetap mempunyai hak-hak tersebut. Inilah sifat universal dari hak-hak tersebut. Selain bersifat universal, hak-hak itu juga tidak dapat dicabut. Artinya seburuk apapun perlakuan yang telah dialami oleh seseorang atau betapapun bengisnya perlakuan seseorang, ia tidak akan berhenti menjadi manusia dan karena itu tetap memiliki hak-hak tersebut.

Narapidana adalah seorang yang dipidana karena telah melakukan perbuatan buruk yang melanggar norma hukum. Sebagai seorang yang menjalani pidana, bukan berarti narapidana kehilangan semua hak-haknya sebagai manusia atau bahkan tidak memperoleh hak apapun selama menjadi narapidana. Hak-hak narapidana telah diatur dalam Sistem Pemasyarakatan. Satu diantara hak tersebut adalah hak untuk mendapatkan pelayanan kesehatan dan makanan yang layak. Menurut Levey dan Lommba (1973) dalam Azrul Azwar ${ }^{3}$,yang dimaksud dengan pelayanan kesehatan adalah setiap upaya yang diselenggarakan sendiri atau secara bersama-sama dalam suatu organisasi untuk memelihara dan meningkatakan derajat kesehatan, mencegah dan menyembuhkan penyakit serta memulihkan kesehatan perseorangan, keluarga, dan ataupun masyarakat.

\footnotetext{
${ }^{3}$ Azrul Aswar 1996. Pengantar Administrasi Kesehatan, Edisi Ketiga, Binarupa Aksara, Jakarta, Hlm, 42
} 
Secara khusus hak atas pelayanan kesehatan bagi warga binaan telah diatur dalam berbagai instrument hukum Nasional. Jaminan pengakuan hak atas kesehatan tersebut dapat dilihat dari beberapa instrumen hukum sebagai berikut :

a. Undang-Undang Nomor 12 Tahun 1995 Tentang Pemasyarakatan

Dalam Undang-Undang No 12 Tahun 1995 Tentang Pemayarakatan, Pasal 14, menyebutkan tentang hak-hak Warga Binaan adalah:

1) Warga Binaan berhak untuk mendapatkan perawatan, baik perawatan rohani maupun jasmani;

2) Warga Binaak berhak untuk mendapatkan pelayanan kesehatan dan makanan yang layak;

3) Warga Binaak berhak untuk menyampaikan keluhan.

b. Peraturan Pemerintah Nomor 32 Tahun 1999 Tentang Syarat-Syarat Dan Tata Cara Pelaksanaan Hak Warga Binaan

Dalam Peraturan Pemerintah Republik Indonesia Nomor 32 Tahun 1999 Tentang Syarat-Syarat Dan Tata Cara Pelaksanaan Hak Warga Binaan ${ }^{4}$, juga menyebutkan bahwa hak-hak Narapidana atas pelayanan kesehatanan adalah sebagai berikut:

Pasal 5

Setiap Narapidana dan Anak Didik Pemasyarakatan berhak mendapat perawatan rohani dan jasmani.

Pasal 6

1) Perawatan rohani sebagaimana dimaksud dalam Pasal 5 diberikan melalui bimbingan rohani dan pendidikan budi pekerti

2) Pada setiap LAPAS wajib disediakan petugas bimbingan rohani dan pendidikan budi pekerti.

3) Dalam melaksanakan bimbingan dan pendidikan sebagaimana dimaksud dalam ayat (1), Kepala LAPAS dapat bekerja sama dengan instansi terkait, badan kemasyarakatan atau perorangan.

Pasal 7

Setiap Narapidana dan Anak Didik Pemasyarakatan berhak mendapat perawatan jasmani berupa:

a. pemberian kesempatan melakukan olah raga dan rekreasi;

b. pemberian perlengkapan pakaian; dan

c. pemberian perlengkapan tidur dan mandi.

Pasal 14

1) Setiap Narapidana dan Anak Didik Pemasyarakatan berhak memperoleh pelayanan kesehatan yang layak.

2) Pada setiap LAPAS disediakan poliklinik beserta fasilitasnya dan disediakan sekurang-kurangnya seorang dokter dan seorang tenaga kesehatan lainnya.

\footnotetext{
${ }^{4}$ Peraturan Pemerintah Republik Indonesia Nomor 32 Tahun 1999 Tentang Syarat-Syarat Dan Tata Cara Pelaksanaan Hak Warga Binaan, Pasal 5,6,7,14,15-23
} 
Pasal 15

1) Pelayanan kesehatan dilakukan oleh dokter LAPAS.

2) Dalam hal dokter sebagaimana ayat (1) berhalangan, maka pelayanan kesehatan tertentu dapat dilakukan oleh tenaga kesehatan lainnya.

Pasal 16

1) Pemeriksaan kesehatan dilakukan paling sedikit 1 (satu) kali dalam 1 (satu) bulan dan dicatat dalam kartu kesehatan.

2) Dalam hal Narapidana atau Anak Didik Pemasyarakatan ada keluhan mengenai kesehatannya, maka dokter atau tenaga kesehatan lainnya di LAPAS wajib melakukan pemeriksaan.

3) Apabila dari hasil pemeriksaan kesehatan sebagaimana dimaksud dalam ayat (1) dan ayat (2) ditemukan adanya penyakit menular atau membahayakan, maka penderita tersebut dirawat secara khusus.

Pasal 17

1) Dalam hal penderita sebagaimana dimaksud dalam Pasal 16 ayat (3) memerlukan perawatan lebih lanjut, maka dokter LAPAS memberikan rekomendasi kepada Kepala LAPAS agar pelayanan kesehatan dilakukan di rumah sakit umum Pemerintah di luar LAPAS.

2) Biaya perawatan kesehatan di rumah sakit bagi penderita dibebankan kepada negara.

3) Dalam hal ada Narapidana atau Anak Didik Pemasyarakatan yang sakit, maka Kepala LAPAS harus segera memberitahukan kepada keluarganya.

Pasal 18

1) Apabila Narapidana atau Anak Didik Pemasyarakatan meninggal dunia karena sakit atau sebab lain, maka Kepala LAPAS segera memberitahukan kepada keluarganya.

2) Jenazah Narapidana atau Anak Didik Pemasyarakatan yang tidak diambil keluarganya dalam jangka waktu 2 x 24 jam sejak meninggal dunia dan telah diberitahukan pada keluarga, penguburannya dilaksanakan oleh LAPAS, sesuai dengan tata cara agama atau kepercayaannya.

Pasal 19

1) Setiap Narapidana dan Anak Didik Pemasyarakatan berhak mendapatkan makanan dan minuman sesuai dengan jumlah kalori yang memenuhi syarat kesehatan.

2) Narapidana dan Anak Didik Pemasyarakatan yang berkewarganegaraan asing, atas petunjuk dokter dapat diberikan makanan jenis lain sesuai dengan kebiasaan di negaranya.

Pasal 20

1) Narapidana dan Anak Didik Pemasyarakatan yang sakit, hamil atau menyusui, berhak mendapatkan makanan tambahan sesuai dengan petunjuk dokter.

2) Makanan tambahan juga diberikan kepada Narapidana yang melakukan jenis pekerjaan tertentu. 
3) Anak dari Narapidana wanita yang dibawa ke dalam LAPAS ataupun yang lahir di LAPAS dapat diberi makanan tambahan atas petunjuk dokter, paling lama sampai anak berumur 2 (dua) tahun.

4) Dalam hal anak sebagaimana dimaksud dalam ayat (3) telah mencapai umur 2 (dua) tahun, harus diserahkan kepada bapaknya atau sanak keluarga, atau pihak lain atas persetujuan ibunya dan dibuat dalam satu Berita Acara.

5) Untuk kepentingan kesehatan anak, Kepala LAPAS dapat menentukan makanan tambahan selain sebagaimana dimaksud dalam ayat (3) berdasarkan pertimbangan dokter

Pasal 21

1) Kepala LAPAS bertanggungjawab atas pengelolaan makanan, yang meliputi:

a. Pengadaan, penyimpanan, dan penyiapan makanan; dan

b. kebersihan makanan dan dipenuhinya syarat-syarat kesehatan dan gizi;

c. pemeliharaan peralatan masak, makan, dan minum

\section{Pasal 22}

Makanan sebagaimana dimaksud dalam ayat (1) sebelum diserahkan kepada Narapidana atau Anak Didik Pemasyarakatan, harus diperiksa terlebih dahulu oleh Petugas LAPAS.

\section{Pasal 23}

Setiap Narapidana atau Anak Didik Pemasyarakatan yang berpuasa, diberikan makanan tambahan.

c. Keputusan Menteri Kehakiman Nomor M. 02-Pk.04.10 Tahun 1990 Tentang Pola Pembinaan Narapidana

Dalam Keputusan Menteri Kehakiman No: M. 02-PK.04.10 Tahun 1990, Tentang Pola Pembinaan Narapidana ${ }^{5}$, menyebutkan bahwa:

Perawatan warga binaan Pemasyarakatan berfungsi untuk menjaga agar mereka selalu dalam keadaan sehat jasmaniah maupun rohaniah, oleh karena itu selalu diusahakan agar mereka tetap memperoleh kebutuhan-kebutuhan dasar yang cukup yaitu kebutuhan pelayanan kesehatan, makanan, air bersih untuk minum, mandi wudhu dan sebagainya

Dalam Kepmen Kehakiman No: M. 02-PK.04.10 Tahun 1990 Tentang Pola Pembinaan Narapidana Bab VII bagian D menyebutkan juga bahwa perawatan warga binaan Pemasyarakatan terdiri dari:

1) Perlengkapan warga binaan

a. Tahanan memakai pakaian sendiri dalam batas yang tidak berlebihan dan tidak mengganggu keamanan serta menun-jukkan kepatutan dan kesopanan.

b. Bagi tahanan yang tidak mempunyai pakaian, diberikan pakaian yang layak dari Lembaga Pemasyarakatan.

${ }^{5}$ Kepmen Kehakiman No: M. 02-PK.04.10 Tahun 1990, Tentang Pola Pembinaan Narapidana bab VII bagian D. 
c. Setiap tahanan diberikan perlengkapan rnakanan, minum, ibadah dan tidur yang layak

2) Makanan warga binaan.

a. Setiap tahanan berhak mendapat jatah makan dan minum sesuai ketentuan yang berlaku.

b. Jumlah kalori makanan diatur sesuai dengan ketentuan yang berlaku dan memenuhi syarat kesehatan.

c. Tahanan yang sakit, hamil, menyusui dan tahanan anak-anak dapat diberikan makanan tambahan sesuai dengan petunjuk dokter.

d. Untuk menyimpan makanan dan pemeliharaan peralatan-nya, dilaksanakan oleh petugas perawatan dengan memperhatikan syarat kebersihan dan kesehatan.

e. Pemasukan bahan makanan untuk penghuni Rutan/Cabrutan harus tertib dan aman sampai di dapur dan sebelum diterima secara resmi, lebih dahulu dicocokkan jumlah, jenis dan mutunya.

f. Di dapur dan di ruang makan digantungkan daftar mingguan tentang menu makanan yang mudah dibaca.

g. Pemberian makanan kepada tahanan dilakukan di tempat yang khusus digunakan untuk ruang makan.

h. Tahanan dapat menerima kiriman makanan dan minuman dari keluarganya, handai taulan dan pihak-pihak lain.

i. Pemasukan bahan makan baik jumlah, jenis maupun mutunya harus sesuai dengan ketentuan yang berlaku dan dibuatkan Berita Acara Penerimaan.

j. Harus menyediakan makan pagi, siang dan sore, sesuai menu, di Ruang Karutan, untuk diteliti apakah sesuai dengan daftar menu setiap hari sesuai jadwal.

k. Perlengkapan makanan dan minuman diberikan, tetapi pemakaian perlengkapan makanan dan minuman yang dapat membahayakan keamanan/ketertiban dilarang.

l. Tahanan yang berpuasa diberikan makanan dan minuman tambahan sesuai dengan ketentuan yang berlaku.

3) Kesehatan warga binaan.

a. Setiap tahanan berhak memperoleh perawatan kesehatan yang layak.

b. Perawatan kesehatan tahanan di Rutan dilakukan oleh dokter Rutan dalam hal tidak ada Dokter Rutan/Cabrutan dapat dilakukan oleh para medis.

c. Pemeriksaan kesehatan dilakukan sekurang-kurangnya satu kali dalam satu bulan, kecuali ada keluhan, maka sewaktu-waktu dapat diperiksa dokter.

d. Atas nasehat Dokter Rutan dan seizin pihak yang menahan tahanan yang sakit dan tidak bisa dirawat di Klinik Rutan, dapat dikirim ke Rumah Sakit Umum atas izin instansi yang menahan dengan pengawalan POLRI/CPM.

e. Apabila ada tahanan yang meninggal dunia karena sakit segera diberitahukan kepada instansi yang menahan dan keluarga tahanan yang bersangkutan serta dimintakan surat keterangan dari Dokter serta dibuatkan Berita Acara oleh Tim yang dituniuk oleh Karutan/ Kacabrutan. 
f. Jenazah yang tidak diambil oleh keluarganya dalam waktu 2 x 24 jam sejak meninggal dunia, padahal telah diberitahukan kepada keluarganya, maka penguburannya dilakukan oleh Rutan/ Cabrutan atau Rumah Sakit.

g. Pengurusan jenazah dan pemakamannya diselenggarakan secara layak menurut agamanya.

Dalam rangka kelancaran pelaksanaan program pelayanan kesehatan di Lapas, maka melalui Surat Keputusan Direktur Jenderal Pemasyarakatan No: E.03.PP.02.10 tahun 2003 telah ditetapkan standar pelayanan minimal pelayanan kesehatan dan makanan Narapidana di Lapas ${ }^{6}$, sebagai berikut :

1) Secara meLembaga pelayanan kesehatan yang ada masih dalam taraf sederhana yaitu pelayanan dokter dan klinik yang sifatnya pertolongan pertama.

2) Rujukan penderita dilakukan secara seadanya, tergantung kondisi pada masing-masing Lapas.

3) Bentuk-bentuk pelayanan promotif, preventif, kuratif dan rehabilitatif dilakukan secara sistimatis

Dari uraian instrumen-instrumen hukum diatas yang mengatur dan menjamin hak atas pelayanan kesehatan bagi warga binaan di Lembaga Pemasyarakatan dapatlah di simpulkan bahwa hak atas pelayanan kesehatan bagi warga binaan di Lembaga Pemasyarakatan mencakup sebagai berikut; ${ }^{7}$

\section{Hak atas ketersediaan (Availability)}

Warga binaan berhak atas ketersediaan fasilitas pelayanan kesehatan, ketersediaan obat-obatan, ketersediaan makanan dan air bersih, serta program-program kesehatan di Lembaga Pemasyarakatan. Hak Narapidana atas ketersediaan fasilitas pelayanan kesehatan di Lapas meliputi;

a. Ketersediaan sumber daya manusia kesehatan (SDMK) di Lapas yang sekurang-kurangnya satu orang dokter, dan satu orang, Perawat, dan ketersediaan tenaga Rohaniawan.

b. Ketersediaan sarana dan prasarana pelayanan kesehatan di Lapas yang meliputi;

- Poliklinik rawat jalan dan rawat inap,

- Perbekalan obat-obatan dan alat-alat kesehatan/kedokteran,

- Sarana pendidikan dan penyuluhan kesehatan,

- Ketersediaan makanan dan minuman yang memenuhi standar kesehatan,

- Ketesedian perlengkapan/alat-alat makan dan minum

- Ketersedian air bersih,

- Ketersediaan sarana sanitasi lingkungan yang baik,

- Ketersediaan kamar mandi dan jamban yang memenuhi dan tempat pembuangan sampah, yang memenuhi standar kesehatan,

- Ketersediaan sarana untuk berolahraga,

- Ketersediaan sarana ibadah sesuai dengan agama dan kepercayaan Narapidana, dan lain-lain.

\footnotetext{
${ }^{6}$ Surat Keputusan Direktur Jenderal Pemasyarakatan No : E.03.PP.02.10 Th. 2003 tentang, Standar Pelayanan Minimal Pelayanan Kesehatan Dan Makanan Narapidana di Lapas

7 Alpan Sarkawi. 2013. Hak Atas Pelayanan Kesehatan bagi Narapidana di Lembaga Pemasyarakatan dalam Upaya Perlindungan Hak Asasi Manusia, Makasar.
} 
c. Ketersediaan anggaran atau pembiayaan pelayanan kesehatan di Lapas

Narapidana berhak untuk mendapatkan jaminan pembiayaan pelayanan kesehatan baik pembiayaan pelayanan kesehatan di dalam Lapas ataupun pembiayaan perawatan kesehatan di tingkat lanjutan yakni di Rumah Sakit dan sarana Kesehatan lainnya.

\section{d. Ketersediaan upaya-upaya pelayanan kesehatan di Lapas}

Narapidana berhak atas ketersediaan program-program atau upaya-upaya pelayanan kesehatan di Lapas yang meliputi; Upaya pelayanan kesehatan Promotif, Preventif, Kuratif dan Rehabilitatif.

\section{Hak atas keterjangkauan (Accessibility)}

Warga binaan berhak untuk tidak diperlakukan diskriminasi terhadap pelayanan kesehatan, artinya bahwa walaupun narapidana dalam keadaan sedang menjalani pemidanaan di Lapas, mereka tetap berhak untuk mendapatkan pelayanan kesehatan sebagaimana masyarakat pada umumnya tanpa diskriminasi terhadap mereka. Selanjutnya mereka mendapatkan hak untuk dapat mengakses pelayanan kesehatan baik secara fisik, ekonomi dan akses atas informasi tentang kesehatan di Lembaga Pemasyarakatan.

Hak atas menerima atau mendapatkan (Acceptability)

Sebagai seorang yang sedang menjalani pemidanaan, Narapidana tetap berhak untuk menerima atau mendapatkan pelayanan kesehatan, hak atas semua pelayanan kesehatan yang diberikan harus sesuai dengan HAM dan etika medis, menjunjung kehormatan pasien atau penghormatan terhadap klien, dan layak secara kultural, Adapun hak-hak Narapidana untuk menerima atau mendapatkan pelayanan kesehatan di Lapas meliputi;

1) Pelayanan kesehatan promotif, Pelayanan kesehatan promotif dimaksud meliputi;

- Kegiatan komunikasi, informasi dan edukasi (KIE) baik secara individual maupun berkelompok.

- Kegiatan konseling, baik secara pribadi maupun kelompok,

- Pemantauan dan pemeliharaan sanitasi dan higiene perorangan.

- Pencegahan penyalahgunaan NAPZA.

- Olah raga rutin dan kompetisi.

2) Pelayanan kesehatan preventif, Pelayanan kesehatan preventif yang meliputi; Lapas.

- Pemeriksaan (screening) awal pada saat pertama kali masuk ke dalam

- Pemeriksaan berkala pada Narapidana, yang minimal 1 bulan sekali.

- Isolasi pada Narapidana yang menderita penyakit menular,

- Pemberian imunisasi,

- Pemantauan dan pembinaan penyelenggaraan makanan bagi Narapidana agar sesuai dengan persyaratan higiene dan sanitasi makanan maupun dengan kebutuhan energi dan nutrisi,

- Pencegahan penyakit menular dan pencegahan penyalahgunaan NAPZA di Lapas, 
- Pemantauan dan surveilens kejadian penyakit menular di Lapas,

- Pemantauan dan pemeliharaan kesehatan lingkungan Lapas

3) Pelayanan kesehatan kuratif, Adapun hak Narapidana terhadap pelayanan kesehatan kuratif di Lapas meliputi;

- Pelayanan pengobatan penyakit umum, termasuk pelayanan kesehatan gigi, sesuai dengan kapasitas yang dimiliki.

- Pelayanan pengobatan penyakit khusus seperti tuberkulosis, malaria, infeksi saluran reproduksi, dan penyakit menular seksual termasuk HIV/AIDS.

- Pelayanan kesehatan rujukan sesuai dengan masalah kesehatan yang dialami Narapidana, baik pelayanan rujukan medis atau pelayanan rujukan Psikososial,

- Pelayanan kesehatan rehabilitatif

- Adapun pelayanan kesehatan rehabilitatif dimaksud meliputi;

- Pelayanan rehabilitasi fisik bagi Narapidana yang mengalami gangguan fisik akibat trauma dan rudapaksa,

- Pelayanan rehabilitasi mental bagi Narapidana yang mengalami masalah kesehatan jiwa dan perilaku,

- Pelayanan rehabilitasi fisik dan mental terhadap Narapidana yang terlibat penyalahgunaan NAPZA,

- Pelayanan rehabilitasi mental terhadap andikpas dengan perilaku seksual berisiko,

- Latihan fisik,

- Konseling perorangan/kelompok

- Bimbingan rohani.,

- Mendapatkan surat keterangan kesehatan

Hak atas kualitas (Quality)

Hak Narapidana untuk mendapatkan pelayanan kesehatan yang berkualitas yang sesuai dengan standar pelayanan kesehatan, yang meliputi;

a. Standar masukan (Input)

Narapidana berhak atas standar masukan pelayanan kesehatan yang meliputi;

1) Standar ketenagaan atau SDM kesehatan di Lapas.

Jumlah tenaga kesehatan pada Unit Pelayanan Kesehatan dan Perawatan di Lapas hendaklah disesuaikan dengan kebutuhan dan jumlah Narapidana yang dibina.

2) Standar fasilitas pada unit pelayanan kesehatan dan perawatan di Lapas

Narapidana berhak atas sarana dan prasarana pelayanan kesehatan di Lapas yang berkualitas atau memenuhi standar.

Adapun fasilitas minimal yang perlu dimiliki oleh unit pelayanan pesehatan dan perawatan di Lapas meliputi;

- Peralatan diagnostik klinik,

- Peralatan untuk tindakan medik,

- Peralatan penunjang pelayanan medik,

- Peralatan penunjang perawatan, 
- Sarana dan prasarana untuk melaksanakan pendidikan kesehatan dan pelayanan konseling

3) Standar pembiayaan kesehatan di Lapas

Narapidana berhak atas pembiayaan kesehatan yang cukup di Lembaga Pemasyarakatan, untuk melaksanakan pelayanan kesehatan yang berkualitas haruslah didukung oleh pendanaan yang cukup, pembiayaan pelayanan kesehatan di Lapas harus disesuaikan dengan jumlah dan kebutuhan Narapidana dan kemampuan yang ada, pembiayaan pelayanan kesehatan bagi Narapidana di Lapas dapat dilaksanakan melalui Program Jaminan Kesehatan Masyarakat (Jamkesmas) atau sumber pembiayaan lainnya.

\section{b. Standar proses (Process)}

Proses pelayanan kesehatan yang berkualitas dimaksud adalah semua tindakan yang dilakukan pada Narapidana di unit pelayanan kesehatan haruslah sesuai dengan standar keperawatan dan standar tindakan medis.

c. Standar lingkungan (Environment)

Narapidana berhak untuk meneriama fisik dan sanitasi lingkungan yang memenuhi standar kesehatan yang meliputi, kamar hunian, kamar mandi, perlengkapan pakaian dan tidur yang cukup, Air bersih yang sesuai dengan standar kesehatan, pembuangan air limbah, tempat pembuangan sampah, dan sanitasi penyelenggaraan makanan yang sesuai dengan standar kesehatan.

\section{d. Standar Keluaran (Output)}

Standar keluaran yang dimaksud disini adalah bahwa pelayanan kesehatan di Lemabaga Pemasyarakatan haruslah dapat memuaskan pemakai jasa pelayanan kesehatan tersebut dalam hal ini Narapidana dan Tahanan

Lembaga Pemasyarakatan selain berfungsi sebagai tempat pembinaan bagi warga binaan, juga berfungsi sebagai tempat pelaksanaan pelayanan kesehatan bagi warga binaan. Fungsi pelayanan kesehatan bagi warga binaan merupakan salah satu penunjang dari program pembinaan jasmani dan rohani terhadap warga binaan. Dalam UndangUndang Nomor 12 Tahun 1995 Tentang Pemasyarakatan ${ }^{8}$, menyebutkan bahwa fungsi Lembaga Pemasyarakatan dalam memberikan pelayanan kesehatan bagi Warga Binaan berupa:

\section{Pasal 14}

1. pelayanan kesehatan bagi Narapidana yang membutuhkan perawatan kesehatan, mulai pertama kali mereka masuk sampai yang bersangkutan bebas.

2. Memberikan surat rujukan kepada Narapidana yang akan melakukan perawatan di Rumah Sakit sesuai dengan jenis penyakit yang dialaminya.

3. Melakukan upaya-upaya pencegahan (preventif) terhadap penyakit menular di lingkungan dalam Lembaga Pemasyarakatan.

4. Melakukan kebersihan lingkungan kamar hunian, perkantoran serta tempat peribadatan agar bebas dari sampah dan kotoran.

\footnotetext{
${ }^{8}$ Undang-undang No. 12 Tahun 1995 Tentang Tentang Pemasyarakatan pasal 14
} 
5. Melakukan koordinasi dengan instansi terkait dalam hal penyelenggaraan pelayanan kesehatan bagi Narapidana.

Dalam melakukan pemenuhan hak tersebut, tentunya terdapat kendala yang menyebabkan tidak dapat berjalan dengan lancar dikarenakan beberapa faktor. Secara garis besar kendala penghambat yang dihadapi oleh pihak Lapas dalam usaha pemenuhan hak mendapatkan pelayanan kesehatan dan makanan yang layak kepada narapidana di Lembaga Pemasyarakatan adalah:

1. Over kapasitas yang kerap terjadi di setiap Lembaga Pemasyarakatan, rata-rata Lapas di Indonesia over kapasitas karena jumlah narapidana yang masuk melebihi dari narapidana yang keluar, sehingga jumlah nya tidak sebanding dan menyebabkan penumpukan narapidana. Hal ini tentu akan berdampak pada kurang optimalnya proses pembinaan. Proses pembinaan akan berjalan baik apabila narapidana dapat menjalanai proses pembinaan dengan keadaan yang sehat fisik maupun mental. Dengan kondisi lapas yang over kapasitas, tentu sangatlah sulit untuk mencapai kondisi narapidana yang ideal untuk dibina. Dengan banyaknya narapidana yang berada di dalam suatu Lapas, entu akan membuat Kurang terjaganya kebersihan di Lapas. Kondisi Lapas yang kurang bersih tentu akan menimbulkan permasalahan baru seperti akan ada banyak narapidana yang menjadi rentan terjangkit berbagai macam penyakit.

2. Kurangnya petugas keahlian khusus di bidang kesehatan untuk menangani para narapidana. Di Lembaga Pemasyarakatan masih kekurangan tenaga - tenaga yang ahli dalam memiliki keahlian khusus seperti tenaga psikolog untuk menunjang kesehatan psikis para narapidana, masih kurangnya tenaga medis yang lebih ahli dan professional dalam melakukan perawatan kesehatan untuk narapidana yang menderita penyakit penyakit yang memerlukan perawatan secara khusus seperti penyakit HIV, Tuberkulosis, Bronkitis dll. Masih tidak adanya juru masak yang ahli dalam mengolah makanan megakibatkan kurang baiknya kualitas makanan yang dihidangkan kepada para narapidana, ditambah lagi tidak adanya ahli gizi di Lapas sepeti yang disebutkan dalam pedoman penyelenggaraan makanan di Lembaga Pemasyarakatan bahwa idealnya proses pemenuhan hak mendapatkan makanan di Lapas harus melibatkan ahli gizi sebagai supervisor dalam proses pengolahan makanan dan juga bertugas untuk membantu proses pemenuhan gizi harian para narapidana.

3. Dana yang terbatas tentu menjadi kendala yang dihadapi pihak Lapas dalam memenuhi hak - hak narapidana karena dengan terbatasnya dana anggaran, membuat proses program pembinaan tidak berjalan dengan baik. Anggaran yang terbatas juga membuat proses pemenuhan hak narapidana untuk mendapatkan pelayanan kesehatan dan makanan yang layak belum sesuai dengan mekanisme terkait pemenuhan hak - hak narapidana sangat bergantung dengan anggaran yang diberikan oleh pemerintah selaku pelaksana program pembinaan. Hal tersebut dapat dibuktikan dengan masih kurang lengkapnya fasilitas - fasilitas yang ada di Lapas untuk menunjaang kebutuhan kebutuhan harian narapidana. Seperti ruang inap, poliklinik dan alat-alat kedokteran lainnya. Hal tersebut tentu harus diatasi dengan melakukan perencanaan aggaran agar proses pembinaan kepada para narapidana Lembaga Pemasyarakatan dapat berjalan dengan maksimal.

\section{PENUTUP}

Berdasarkan penjelasan diatas, maka penulis menarik kesimpulan bahwa pemenuhan hak pelayanan kesehatan kepada narapidana untuk di Lembaga 
Pemasyarakatan belum berjalan secara maksimal. Dalam Undang-Undang bahwa hak atas pelayanan kesehatan bagi warga binaan di Lembaga Pemasyarakatan mencakup hak atas ketersediaan (availability), hak atas keterjangkauan (accessibility), hak atas menerima atau mendapatkan (acceptability), hak atas kualitas (quality). Pemerintah serta Pemasyarakatan telah berusaha untuk mebuat berbagai peraturan tentang pelayanan kesehatan kepada narapidana dengan sangat rinci dengan tujuan peraturan tersebut dapat dijadikan pedoman dalam melaksanakan program pembinaan dan pemberian hak kesehatan kepada narapidana di Lembaga Pemasyarakatan. Namun, dalam pelaksanaannya sangat sulit apabila dilakukan sesuai dengan peraturan yang ada, karena kondisi yang diharapkan berbeda dengan kondisi pada realita. Pada kenyataannya, dalam Lembaga Pemasyarakatan ditemukan berbagai macam kendala yang dihadapi pihak Lembaga Pemasyarakatan, kendala - kendala tersebut antara lain adalah over kapasitas yang terjadi di Lapas, masih kurangnya petugas khusus dibidang kesehatan yang ada di Lembaga Pemasyarakatan dan juga pihak Lapas masih terkendala masalah anggaran dana yang terbatas.

\section{DAFTAR PUSTAKA}

Alpan, Sarkawi, 2013 . Hak Atas Pelayanan Kesehatan bagi Narapidana di Lembaga Pemasyarakatan dalam Upaya Perlindungan Hak Asasi Manusia , Mksr.

Azrul Aswar. Pengantar Administrasi Kesehatan, Edisi Ketiga, Binarupa Aksara, Jakarta, Hlm, 42

Jumalia, 2017. Peran Pemerintah Dalam Pemenuhan Hak Narapidana Untuk Memperoleh Pelayanan Kesehatan, Pontianak

Kepmen Kehakiman No: M. 02-PK.04.10 Tahun 1990, Tentang Pola Pembinaan Narapidana bab VII bagian D.

Muhammad Farid, 2015. Implementasi Hak Mendapatkan Pelayanan Kesehatan dan Makanan yang Layak bagi Narapidana di Lembaga Pemasyarakatan, Makasar

Peraturan Pemerintah Republik Indonesia Nomor 32 Tahun 1999 Tentang Syarat Syarat Dan Tata Cara Pelaksanaan Hak Warga Binaan, Pasal 5,6,7,14,15-23 Peraturan Pemerintah Republik Indonesia Nomor 32 Tahun 1999 Tentang Syarat-Syarat Dan Tata Cara Pelaksanaan Hak Warga Binaan, Pasal 5,6,7,14,15-23 